\title{
FUNCTIONAL RELATIONSHIPS BETWEEN MOISTURE AT SEVERAL EQUILIBRIUM POINTS AND THE CLAY CONTENT OF TROPICAL SOILS
}

\author{
M. A. LUGO-LÓPEZ
}

\section{INTRODUCTION}

It is generally accepted that soils are able to hold moisture in proportion to their content of clay particles, provided their clay complex is similar mineralogically, and that their level of organic matter is more or less on an equal basis. In temperate regions, attempts have been made to measure quantitatively the influence of the clay fraction in the ability of the soils to retain moisture at various levels. No similar work, however, has been reported from workers in the Tropics. This paper presents the results of an attempt to evaluate the moisture content throughout the whole $\mathrm{pF}$ range of Puerto Rico soils on the basis of their percentage of clay.

It is of fundamental importance to establish with certainty the nature of such a relationship. If reliable regressions are obtained, agronomists and practical agriculturists will have an easy way to make acceptable predictions concerning the moisture relationships of tropical soils on the basis of their clay content.

\section{MATERIALS AND METHODS}

Samples were collected in the humid region in areas where lateritic soils are predominant and in areas of nonlateritic soils. Seventy-one sites were sampled, 19 of which occur in the former area and 52 in the latter. In sampling an area, the maps of the Soil Survey of Puerto Rico were used as a guide in the field (5). ${ }^{2}$ The soil descriptions were checked with field observations to make certain that the samples corresponded to the series under consideration. Composite samples were obtained following the procedure outlined by Cline (2) from the topmost 6 to 8 inches. Each composite consisted of several units. The samples were then air-dried and passed through a $2-\mathrm{mm}$. sieve. Undisturbed cores of soil were also taken for bulk density determinations.

Total porosity values were taken as indices of the maximum saturation values for each soil. To estimate the porosity, true density was determined by using the picnometer, and bulk density by drying an undisturbed core of soil to constant weight at $105^{\circ} \mathrm{C}$. Field capacity measurements were made by using the technique suggested by Weaver and Clements (8).

${ }^{1}$ Associate Soil Scientist, Agricultural Experiment Station, University of Puerto Rico, Río Piedras, Puerto Rico.

${ }^{2}$ Numbers in parentheses refer to Literature Cited, pp. 69-70. 
The moisture equivalents were determined by means of a special centrifuge following the method outlined by Briggs and McLane (1). The standard biological method (6) with soybeans as indicator plants, was used in determining the permanent wilting percentage. Soil samples were brought to equilibrium with 3.3 percent sulfuric acid solution in order to obtain values for hygroscopic coefficients. Clay contents were found by making

TABLE 1.-Relation between moisture at several critical points and the clay content of lateritic and nonlateritic soils

\begin{tabular}{|c|c|c|c|}
\hline Group & Functional relationship & $\begin{array}{l}\text { Coefficient } \\
\text { of deter- }_{\text {mination }}\end{array}$ & $\begin{array}{l}\text { Correlation } \\
\text { coefficient }^{2}\end{array}$ \\
\hline \multirow{5}{*}{ Lateritic } & $\begin{array}{l}\text { Maximum saturation }=40.90+0.44 \text { (percent } \\
\text { clay) }\end{array}$ & 0.74 & +0.86 \\
\hline & $\begin{array}{l}\text { Field capacity }=10.02+1.65 \text { (percent clay)- } \\
0.020 \text { (percent clay) })^{2}\end{array}$ & .83 & +.91 \\
\hline & $\begin{array}{l}\text { Moisture equivalent }=3.67+1.69 \text { (percent } \\
\text { clay) }-0.018 \text { (percent clay) }{ }^{2}\end{array}$ & .84 & +.92 \\
\hline & $\begin{array}{l}\text { Permanent wilting percentage }=5.80+0.53 \\
\quad \text { (percent clay) }\end{array}$ & .80 & +.89 \\
\hline & $\begin{array}{l}\text { Hygroscopic coefficient }=3.11+0.41 \text { (percent } \\
\text { clay) }\end{array}$ & .71 & +.84 \\
\hline \multirow{5}{*}{ Nonlateritic } & $\begin{array}{l}\text { Maximum saturation }=45.30+0.36 \text { (percent } \\
\text { clay) }\end{array}$ & .34 & +.57 \\
\hline & $\begin{array}{l}\text { Field capacity }=10.98+1.70 \text { (percent clay)- } \\
0.022 \text { (percent clay) })^{2}\end{array}$ & .84 & +.92 \\
\hline & $\begin{array}{l}\text { Moisture equivalent }=3.56+1.89 \text { (percent } \\
\text { clay) }-0.023 \text { (percent clay) })^{2}\end{array}$ & .83 & +.91 \\
\hline & $\begin{array}{l}\text { Permanent wilting percentage }=3.28+0.53 \\
\quad \text { (percent clay) }\end{array}$ & .76 & +.87 \\
\hline & $\begin{array}{l}\text { Hygroscopic coefficient }=3.23+0.36 \text { (percent } \\
\text { clay) }\end{array}$ & .72 & +.85 \\
\hline
\end{tabular}

${ }^{1}$ Is the ratio of the difference between the squared standard deviation and the squared standard error of estimate to the original variability. Indicates the proportion of the variability in moisture which can be explained on the basis of the clay content.

2 Indicates the closeness of the relationship between moisture and clay content.

use of the hydrometer technique (3). The least squares method (4) was employed in the correlation analysis of the data obtained.

\section{PRESENTATION OF RESULTS}

The statistical interpretation of the data is presented in table 1 for lateritic and nonlateritic soils.

At maximum saturation, when the total pore space of soils was com- 
pletely filled with water, a positive linear correlation was evident in both groups of soils, indicating very moderate increases in saturation with unit increases in clay content. A positive correlation coefficient of the order of 0.86 was obtained for lateritic soils which explains three-fourths of their variability in moisture at the uppermost range of the scale on the basis of the percentage of clay particles. In nonlateritic soils of the humid Tropics only one-third of the variability observed could be accounted for by taking the clay content as a basis independently from other factors.

A highly significant correlation is evident between the moisture retained at field capacity by both lateritic and nonlateritic soils and that fraction of the soil dominated by particles smaller than $0.002 \mathrm{~mm}$. More than 80 percent of the variability in field capacity can be ascribed to variations in clay content. In both groups of soils there is a marked tendency for increasing moisture values to occur with increasing clay contents until a certain level is reached. Afterwards, the increases in clay accompany increased moisture at only a decreasing rate until a point is reached where further increments of clay have no effect on the water-retaining power of the soil.

The same general relationship holds between moisture equivalent and clay. The same curvilinear pattern is observed as indicated by the regressions on table 1 . The correlation is also highly significant in this case when only about 16 and 17 percent of the variability observed for lateritic and nonlateritic soils, respectively, cannot be explained on the exclusive basis of the clay content of the soil.

A definite linear relationship exists between the permanent wilting percentage and the clay content. The correlation for all humid soils is very high indeed. The clay content explains more than 80 percent and 75 percent of the variability occurring in the permanent wilting percentages of lateritic and nonlateritic soils respectively.

The soils of the humid Tropics continue to exhibit a very close degree of association between their moisture equilibrium points and their clay percentage, even at the lower end of the range represented by the hygroscopic coefficient. The variability in moisture content at that point is mostly accounted for by the variation in clay content of the soils.

\section{DISCUSSION}

The relationships presented indicate that rather accurate predictions of the moisture content at all equilibrium points can be made on the basis of the percentage of clay in the lateritic soils. As for the nonlateritic soils of the humid area, it is apparent that very significant predictions are possible in the lower and middle scale of moisture values ranging from hygroscopic 
coefficient to field capacity. However, as the point of maximum saturation is approached, the clay content can no longer be used as a very reliable index. The regressions presented in table 1 are particularly valuable, since they facilitate the evaluation of several physical constants of the soil without their direct determination. A knowledge of the clay content of soils of the humid Tropics can serve as a key to a rather precise body of information concerning their moisture relationships.

\section{SUMMARY}

The tropical soils of the humid region studied in this investigation have been grouped into two broad categories: (a) Lateritic and (b) nonlateritic. Regression equations are presented which may serve to predict any of the moisture constants considered, namely, maximum saturation, field capacity, moisture equivalent, permanent wilting percentage, and hygroscopic coefficient, on the exclusive basis of the clay content of the soils. Very high correlations were obtained in all cases for lateritic soils. Very high correlations were also found for the nonlateritic soils of the humid Tropics, excepting the values for maximum saturation.

\section{RESUMEN}

Los suelos tropicales de la región húmeda de Puerto Rico que se usaron en esta investigación fueron agrupados en dos categorías: (a) Lateríticos y (b) no-lateríticos. Se presentan ecuaciones de regresión que pueden servir para predecir, a base del contenido de arcilla de los suelos exclusivamente, las constantes estudiadas, a saber: Saturación máxima, capacidad de campo, equivalente de humedad, punto de marchitez permanente y coeficiente de higroscopicidad. Se obtuvieron índices de correlación altamente significativos en cada caso para suelos lateríticos. En suelos no-lateríticos la correlación fué también altamente significativa en todos los casos con excepción de la correlación entre la saturación máxima y el contenido de arcilla.

\section{ACKNOWLEDGMENT}

The writer wishes to express his appreciation to Dr. B. G. Capó, Assistant Director for Research of this Station, for his valuable help in the statistical interpretation of the data.

\section{LITERATURE CITED}

1. Briggs, L. J., And McLane, J. W. The moisture equivalent of soils. U.S.D.A. Bur. of Soils Bul. 45. 1907.

2. Curne, M. G. Methods of preparing and collecting soil samples. Soil Sc. 59: 3-5. 1945 . 
3. Kilmer, V. J., And Alexander, L. T. Methods of making mechanical analysis of soils. Soil Sc. 58: 15-24. 1949.

4. Pearson, F. A., and Bennet, K. R. Statistical methods. New York. John Wiley and Sons, Inc. 1942.

5. Roberts, R. C. Soil Survey of Puerto Rico. U.S.D.A. Bur. of Plant Ind. in cooperation with P. R. Univ. Agr. Exp. Sta. Series 1936. No. 8, 1942.

6. Veihmeyer, F. J., And Hendrickson, A. H. Methods of measuring field capacity and permanent wilting percentage of soils. Soil Sc. 68: 75-94. 1949.

7. Veihmeyer, F. J., ANd Hendrickson, A. H. The moisture equivalent as a measure of the field capacity of soils. Soil Sc. 32: 181-193, 1931.

8. Weaver, J. E., And Clements, F. E. Plant Ecology. New York. McGraw Hill Book Company, Inc. 1938. 